[Case report]

\title{
Thoracoscopic Lung Lobectomy for a Lung Cancer Patient with Situs Inversus Totalis
}

\author{
Masatoshi Kanayama $^{1 *}$, Masaaki Inoue ${ }^{1}$, Junichi Yoshida ${ }^{1}$ and Fumihiro TAnaKA ${ }^{2}$ \\ ${ }^{1}$ Department of Chest Surgery, Shimonoseki City Hospital, Shimonoseki 750-8520, Japan \\ ${ }^{2}$ Second Department of Surgery, School of Medicine, University of Occupational and Environmental Health, Japan. \\ Yahatanishi-ku, Kitakyushu 807-8555, Japan
}

\begin{abstract}
Situs inversus totalis is a rare clinical condition that represents a complete mirror image of the normal arrangement of the thoracic and abdominal viscera. There are very few reported cases of lung cancer patients with situs inversus totalis, but this condition requires particular care during surgery. A 61-year-old woman presented to our hospital with an abnormal shadow on chest radiography. Computed tomography revealed a $25 \times 12 \mathrm{~mm}$ solitary pulmonary nodule in the left upper lobe (S2) and a complete mirror image of the normal organ arrangement, which findings met the criteria of situs inversus totalis. Preoperative examination revealed left upper lobe lung cancer (c-T1bN0M0 Stage IA), and surgery was planned for diagnosis and treatment. Before the surgery, three-dimensional CT images were reconstructed for a precise evaluation of the pulmonary vessels and bronchi. The nodule was microscopically diagnosed as adenocarcinoma from a frozen section obtained by wedge resection. We performed a left upper lobectomy with lymph node dissection using video-assisted thoracic surgery. The aortic arch was absent from the left thoracic cavity and the left lung was well lobulated into three lobes. Although it revealed a mirror image of the usual arrangement, we could accomplished in the usual procedure and process. Careful preoperative anatomical evaluation and perioperative handling are essential for the prevention of intraoperative injuries and complications in patients with situs inversus totalis.
\end{abstract}

Keywords : thoracoscopic lung lobectomy, lung cancer, situs inversus totalis.

(Received May 29, 2018, accepted August 20, 2018)

\section{Introduction}

Situs inversus totalis (SIT) is a congenital and autosomal recessive genetic disease that is connected with X-chromosome defect, and the frequency of SIT is $1-2 / 10,000$ newborns [1]. SIT involves a complete reversal of the normal arrangement of the thoracic and abdominal viscera [2], and it requires particular care to prevent complications during surgery. Here we describe a successful thoracoscopic lung lobectomy for a lung cancer patient with SIT.

\section{Case Report}

A 61-year-old woman with SIT was referred to our hospital because of an abnormal shadow on chest radiography. Chest computed tomography (CT) revealed an irregularly shaped nodule (measuring $25 \times 12 \mathrm{~mm}$ in diameter) in the left upper lobe (S2) attached to the interlobar pleura (Fig. 1A) and SIT (Fig. 1B). Bronchoscopy confirmed that the left and right bronchial branches were mirror images of each other. As we were unable to obtain a definitive diagnosis by the bronchoscopic approach,

*Corresponding Author: Masatoshi KanaYama, Department of Chest Surgery, Shimonoseki City Hospital, Japan. 1-13-1 Koyo-machi, Shimonoseki 750-8520, Japan, Tel: +81-83-231-4111, Fax: +81-83-224-3838, E-mail: masatoshi-kanayama@med.uoeh-u.ac.jp 

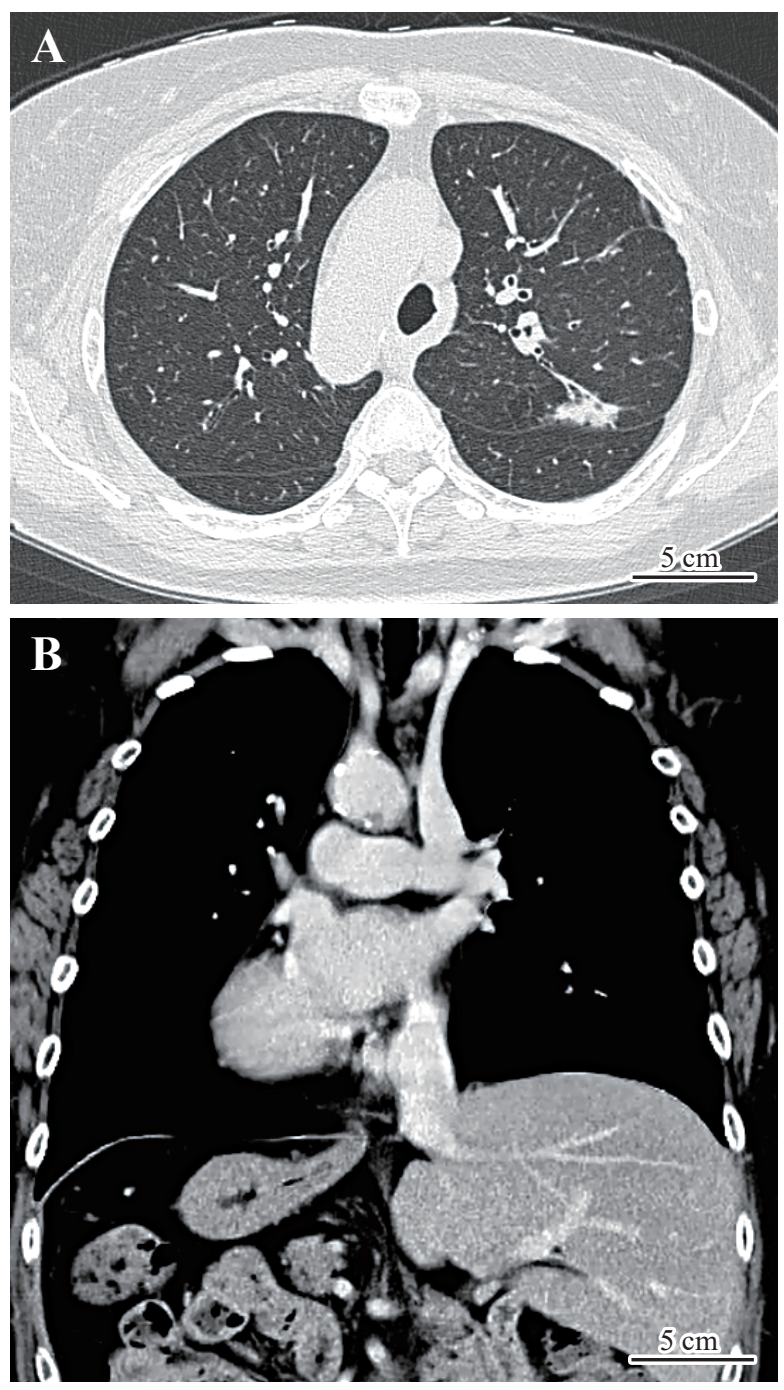

Fig. 1. The radiological findings of pulmonary tumor and thoracic anatomy. Chest computed tomography (CT) revealed an irregularly shaped nodule (measuring $25 \times 12$ $\mathrm{mm}$ in diameter) in the left upper lobe (S2) attached to the interlobar pleura (A). CT image in the coronary section revealed a mirror image of the usual arrangement of the organs, vessels, and bronchi (B).

surgery was planned for diagnosis and treatment. Before the surgery, three-dimensional CT (3D-CT) images were reconstructed for a precise evaluation of the pulmonary vessels and bronchi (Fig. 2A, B). Intraoperatively, we established that the location of the superior vena cava and azygos vein mirrored the normal distribution, and that the aortic arch was absent from the left thoracic cavity. The left lung was well lobulated into three lobes and the anatomy of the left side of the pulmonary artery had features typical of the normal right side (Fig. 3A, B).
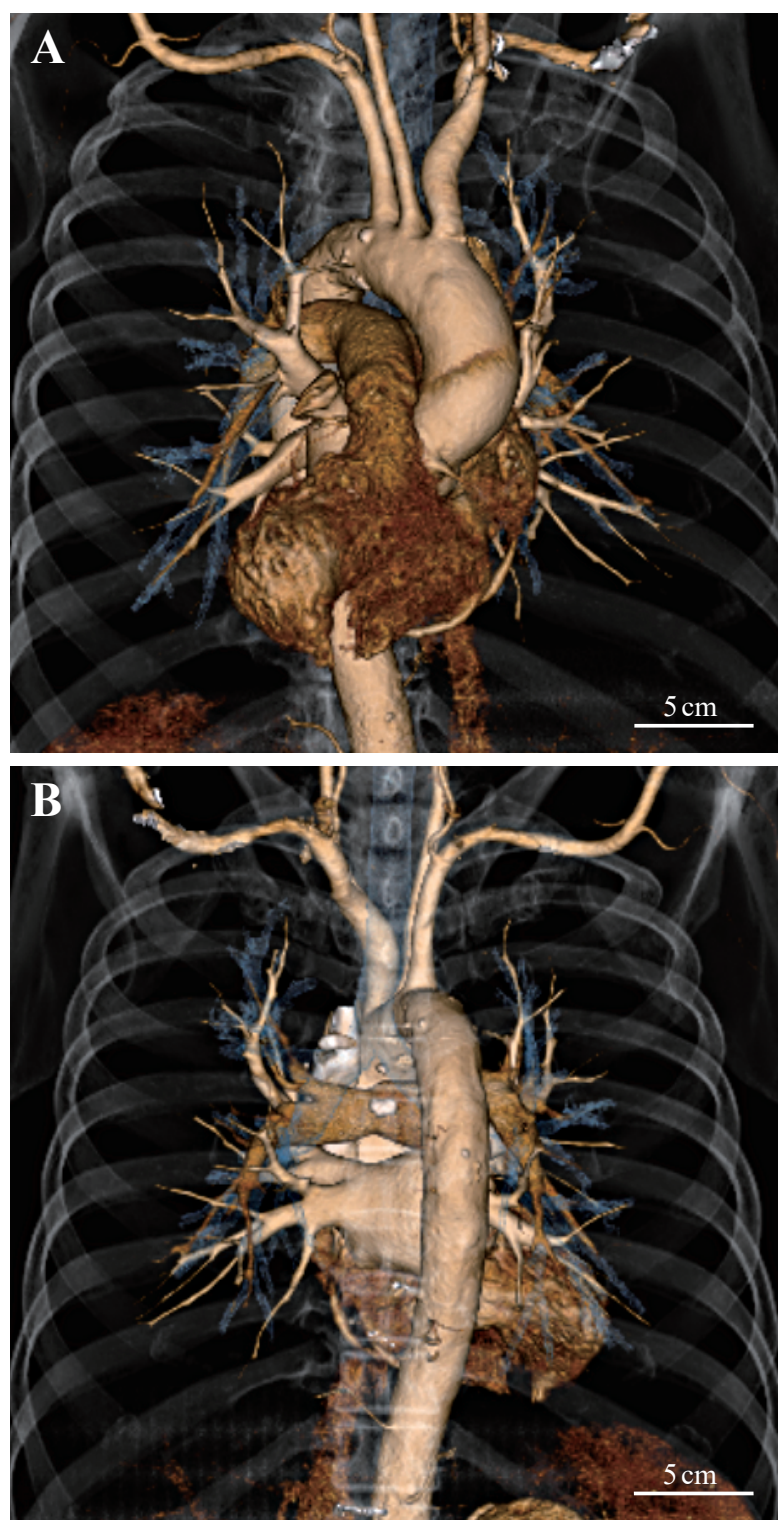

Fig. 2. The radiological findings of thoracic anatomy. Three-dimensional chest computed tomography (CT) revealed a mirror image of the normal arrangement of the organs, vessels, and bronchi. A: Anterior image, B: Posterior image.

The nodule was located in the left upper lobe (S2), and we removed it by wedge resection. The frozen section revealed the proliferation of malignant cells, suggesting adenocarcinoma. Therefore, we performed left upper lobectomy with lymph node dissection (ND2a-1) using VATS (3 ports). We did not observe any malformations other than the mirror image of the organs. The operation took 3 hours and 15 minutes to complete, with minimal, intraoperative blood loss. The final pathological diagnosis was adenocarcinoma, p-T1b $(12 \times 12 \mathrm{~mm})$ N0M0, p- 

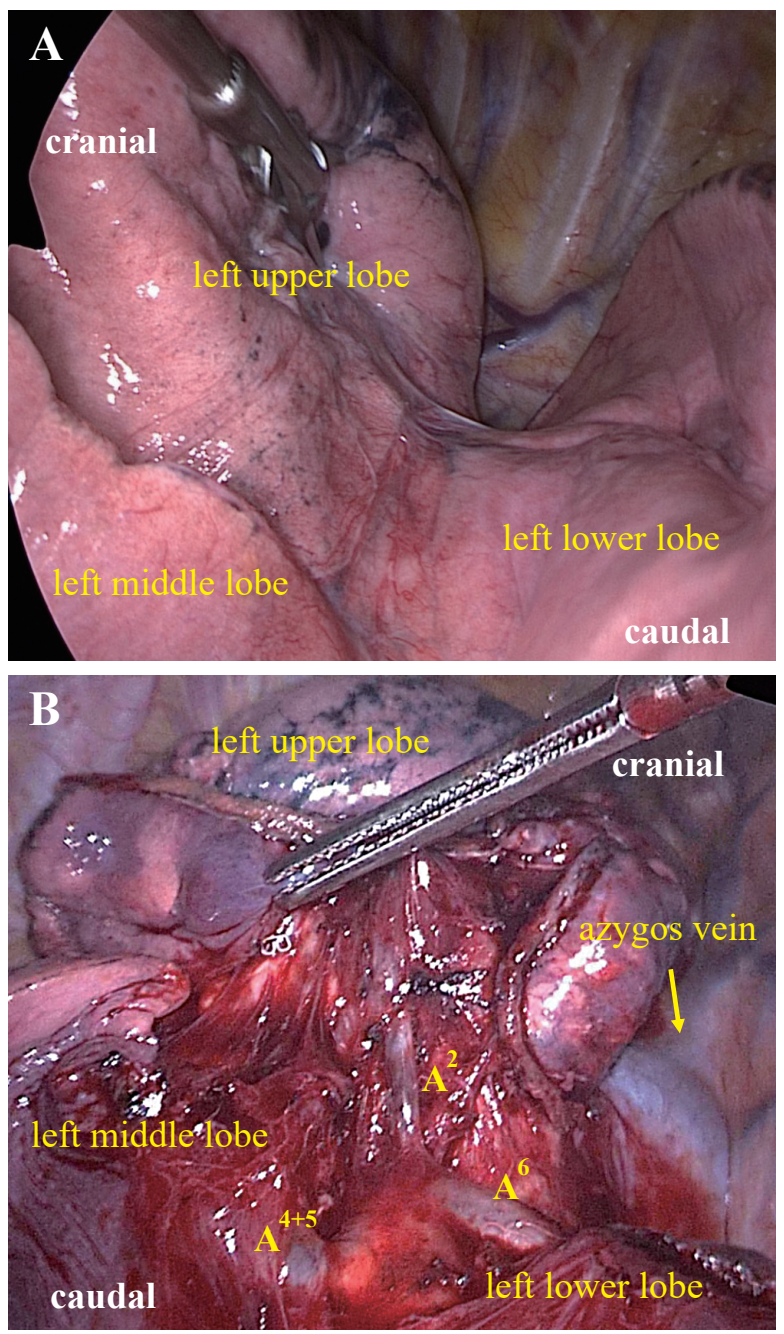

Fig. 3. Intraoperative findings of thoracic anatomy. Intraoperative findings showing that the location of the superior vena cava and azygos vein mirrored the normal distribution, and that there was no aortic arch in the left thoracic cavity. The left lung was well lobulated into three lobes (A), and the anatomy of the left side of the pulmonary artery had features typical of the normal right side (B). $\mathrm{A}^{2}$ : pulmonary artery $\mathrm{A}^{2}$, $A^{4+5}$ : pulmonary artery $A^{4+5}, A^{6}$ : pulmonary artery $A^{6}$.

Stage IA2 (Union for International Cancer Control, 8th $e d$.). The patient's postoperative course was uneventful, and she was discharged from our hospital on postoperative day 9 .

\section{Discussion}

Situs inversus totalis (SIT) is an uncommon condition in which the heart and other organs of the body are transposed through the sagittal plane to lie on the opposite side from the normal position. $20-25 \%$ of this condition is associated with Kartagener's syndrome [3]. A relationship between lung cancer and SIT has not yet been elucidated, and medical reports of lung cancer patients with SIT are extremely rare; only 16 surgical cases (13 thoracotomies and 3 VATS) have been reported so far.

SIT itself has no pathological significance, but this condition requires careful attention during surgery. In SIT, not only are the organs reversed sagittally, but there may also be some variations in the courses of the pulmonary vessels and bronchi. Therefore, it is essential for surgeons to take extreme care in identifying and handling the vascular and bronchial branches of the contralateral thoracic cavity [4]. Wójcik et al reported that "all authors confirmed the consistency of contrast-enhanced CT for detecting the anatomical conditions observed during the operation" [5]. 3D-CT is useful to understand the mirror-imaged anatomy three-dimensionally and to prevent the risk of vascular and bronchial injury.

Unlike pulmonary vessels and bronchi, neurological structures are more difficult to capture by preoperative imaging, and this difficulty is compounded by the fact that we rarely encounter patients with SIT. Because the location of the left recurrent laryngeal nerve was unclear at the beginning of the present operation, the upper mediastinal lymph node dissection had to be performed very carefully so as not to injure the recurrent laryngeal nerves. These precautions probably ensured the uneventful postoperative course.

The present patient was free of Kartagener's syndrome, but if that condition were to exist, the case could be complicated by intrathoracic adhesions and an irregular and expanded bronchial artery due to chronic and repeated infections [6]. Surgeons should consider these possibilities and make appropriate preoperative preparations.

\section{Conclusion}

In conclusion, we present an extremely rare case of thoracoscopic lung lobectomy for a lung cancer patient with SIT. Cautious preoperative anatomical evaluation and perioperative handling are essential to prevent intraoperative injuries and complications in cases involving SIT. 


\section{Conflicts of Interest}

The authors declare no conflicts of interest.

\section{References}

1. Abossolo T, Alessandri JL, Saltet A, Dancoisne P, Pilorget H \& Sommer JC (1996): In utero diagnosis of situs abnormalities. A case of prenatal diagnosis of visceral situs inversus with corrected transposition of great vessels. J Gynecol Obstet Biol Reprod 25: 267-273

2. Subotich D, Mandarich D, Katchar V, Bulajich B \& Drndarski B (2006): Lung resection for primary bronchial carcinoma in a patient with complete situs inversus. Clin Anat 19: 358-362
3. Douard R, Feldman A, Bargy F, Loric S \& Delmas V (2000): Anomalies of lateralization in man: a case of total situs inversus. Surg Radiol Anat 22: 293-297

4. Shimizu J, Arano Y, Adachi I, Morishita M, Fuwa B, Saitoh M \& Minato H (2011): Adenosquamous carcinoma of the lung in a patient with complete situs inversus. Ann Thorac Cardiovasc Surg 17: 178-181

5. Wójcik J, Grodzki T, Bielewicz M, Wojtyś M, Kubisa B, Pieróg J \& Wójcik N (2013): Lung cancer in situs inversus totalis (SIT) - literature review. Adv Med Sci 58: $1-8$

6. Inoue Y, Suga A, Sekido Y, Yamada S \& Iwazaki M (2011): A case of surgically resected lung cancer in a patient with Kartagener's syndrome. Tokai J Exp Clin Med 36: 21-24 
完全内臓逆位に合併した肺癌に対する胸腔鏡下肺葉切除術

金山 雅俊 ${ }^{1}$ ，井上 政昭 ${ }^{1}$, 吉田 順一 ${ }^{1}$, 田中 文啓 ${ }^{2}$

1 下関市立市民病院 呼吸器外科

2 産業医科大学 医学部 第2外科学講座

要旨：完全内臟逆位は, 各臟器が左右逆転し正常位に対して鏡面像的位置関係にあるものをいい, 頻度は 10,000 人に 1 2 人と稀に2られる常染色体劣性遺伝の破格である. 今回, 完全内臓逆位に合併した原発性肺癌に対 して, 胸腔鏡下手術を施行した報告をする。症例は 61 歳女性. 胸部X線写真で左上肺野に異常陰影を指摘され紹介 となる．胸腹部 CTにて胸腹部内臓の完全逆位に加え, 左肺上葉 $\mathrm{S} 2$ に葉間胸膜に接する $25 \times 12 \mathrm{~mm}$ の結節影を認め た. 術前検查にて左上葉肺癌疑い c-T1bN0M0 Stage IA として手術を行う方針とした. 術前3D構築画像にて鏡面像 を呈した肺動静脈および気管支の立体的構造を把握した。手術は腫瘍を胸腔鏡下に部分切除を行い, 迅速病理検查 で腺癌と診断されたため完全胸腔鏡下に左上葉切除およびリンパ節郭清を施行した。左縦隔に下行大動脈は認め ず, 左肺は上中下葉の3葉に分葉していた，左右鏡面像であったが, 正常解剖の際の手技, 手順で施行可能であった. 完全内臟逆位の手術においては,つねに反対側の胸腔をイメージしながらの手術となる，そのため術前に肺血管,気 管支の解剖学的評価を十分に行った上での慎重な手術操作が必要となる.

キーワード : 胸腔鏡下肺葉切除, 肺癌, 完全内臟逆位. 